\title{
The Importance of Environmental Education \\ in Indonesian Language Learning
}

Zha Zha Nurul Afryani /18016199

zhazha0042@gmail.com

The environment is one of the most important factors in the life process. The environment can shape the human mindset. In addition to being able to form a human mindset, the environment indirectly changes the way a person perceives a variety of problems. This can lead to a process that has not been realized so far, namely that the environment is able to shape humans, and humans can also form the environment. Soemarwoto (2007) in Sukma et.al (2015) said that the environment determines human survival. The environment becomes a place to interact and learn. In his environment, humans know various languages, cultures, and natural conditions that can increase intelligence ecological.

According to Ramadhan et.al. (2019), Environmental education is important to increase students' attitudes and awareness of the environment. Environmental education is able to enable students to think critically and contextually. This ability of students to think critically and contextually is very useful in the process of learning Indonesian, so as to create a learning process that integrates environmental education and language learning.

The environment is at the forefront of shaping the human mindset, which can be integrated into the language learning process. In a language learning there is an interaction between students and language. According to Sukma. (2005), the use of language is closely related to the social relations between language speakers in society. This social relationship relates to students 'communication skills, students' understanding of language use, and the way students sort out the language they will use.

Ramadan et.al. (2019), said that language learning focuses on the process of language skills which directly makes students gain any knowledge. According to Sukma and Johari. (2016), language learning is an interesting learning. Sukma (2016) states that language learning requires a teacher to be able to develop various tekni $\mathrm{k}$ and a variety of techniques that able to increase students' interest in learning. Teachers must know 
what their students need, not just meaningless learning. Sukma et.al, (2019). states that teachers should provide material that is suitable for students' conditions, age, interests, habits, and life environment .

According to Ramadhan et.al, (2019). in Indonesia, environmental education is not a compulsory subject in schools. Therefore, environmental education can be integrated into pe disable in the other, one of which is learning the language. Ramadan et.al. (2019), said that the use of environmental themes in text learning can trigger students 'interest in learning languages and can implicitly increase students' knowledge of the environment . Omidvar and Sukumar (2013) in Ramadhan et.al (2019) say that integrating language learning with environmental themes can open opportunities for students to develop students' thinking and communicative skills by using materials that challenge global issues, especially about the environment.

According to Ramadhan et.al. (2015), students have the ability to abstract concepts. This ability cannot be separated from other students' abilities such as their high curiosity, strong desire, and very fond of challenges. According to Ramadhan et.al. (2018), innovative learning models can improve student learning outcomes. Therefore, integrating environmental education into the language learning process is the right step in exploring students' abilities so that students can innovate and collaborate with the environment around them.

Based on the questionnaire that has been in the spread to 32 students of the fifth semester in 2020 from the University of Ne geri Padang, Andalas University, the University of Bung Hatta, Poltekes Ministry of Health, the State Islamic University of Imam Bonjol, and University of Edinburgh. From the total number of respondents who participated in filling out the questionnaire, it was found that women were much more dominant than men, with a percentage of $93.8 \%$ women, $6.3 \%$ men. Pene Litian is done using the google form, the author provides 10 statements that must be completed by the respondent. The first statement, the environment has an influence on the Indonesian language learning process, which states strongly agree ( $50 \%)$, agree $(50 \%)$, disagree $(0 \%)$, and disagree $(0 \%)$.

The second statement, learning Indonesian and the environment is one thing that cannot be separated, which states agree ( $65.6 \%)$, strongly agree $(34.4 \%)$, disagree (0\%), and 
disagree $(0 \%)$. The third statement is that the environment can have a positive impact on the Indonesian language learning process. who agree ( $62.5 \%)$, strongly agree $(37.5 \%)$, disagree $(0 \%)$, and disagree $(0 \%)$. The fourth statement, the environment can be used as a medium in the Indonesian language learning process, which states agree (50\%), strongly agree ( $46.9 \%)$, disagree $(3.1 \%)$, and disagree ( $0 \%)$. The fifth statement, environmental material can foster student creativity in the language learning process, which states agree $(62.5 \%)$, strongly agree $(34.4 \%)$, disagree $(3.1 \%)$, and disagree $(0 \%)$. The sixth statement, environmental material needs to be included in the Indonesian language learning material, which states agree ( $75 \%$ ), strongly agree ( $21.9 \%$ ), disagree $(3.1 \%)$, and disagree $(0 \%)$. The seventh statement, providing environmental material in Indonesian language learning is an effort to build ecological intelligence, which states agree (62.5\%), strongly agree (31.3\%), disagree (6.3\%), and disagree ( $0 \%$ ). The eighth question, environmental material is very closely related to daily life, they strongly agree ( $56.3 \%$ ), agree ( $43.8 \%$ ), disagree $(0 \%)$, and disagree $(0 \%)$. The ninth statement, environmental material can foster a sense of interest towards Indonesian, which states agree ( $75 \%$ ), strongly agree (15.6\%), disagree $(9.4 \%)$, and disagree $(0 \%)$. The tenth statement, environmental material can make students think comprehensively, which states agree (65.6\%), strongly agree (28.1\%), disagree $(6.3 \%)$, and disagree $(0 \%)$.

Based on the results of the research conducted by the author, it can be concluded that environmental education is closely related to Indonesian language learning, because the environmental material integrated into Indonesian language learning is able to make students think creatively, comprehensively, and innovatively. In addition, the environment can be used as a medium for language learning to build ecological intelligence and a sense of waterproof love. 


\section{Reference}

Amelia, Rizky, Elfia Sukma, dan Nur Asma. (2015). Pembelajaraan Menulis Laporan Percobaan Dengan Pendekatan Saintifik di Sekolah Dasar. Prosiding Seminar Nasional Jurusan PGSD FIP UNP. Vol.1, No.1

Indriyani, Vivi, M. Zaim, Atmazaki, dan Syahrul Ramadhan. (2019). Literasi Baca Tulis Dan Inovasi Kurikulum Bahasa. KEMBARA: Jurnal Keilmuan Bahasa, Sastra, dan Pengajarannya. Vol. 5, No. 1

Ramadhan, Syahrul, Atmazaki, Zulhafizh. (2013). Kontribusi Sikap dan Motivasi Belajar Siswa terhadap Hasil Belajar Bahasa Indonesia. Jurnal Bahasa, Sastra, dan Pembelajaran. Vol.1, No.2

Ramadhan, Syahrul, Elfia Sukma dan V Indriyani. (2019). Environmental education and disaster mitigation through language learning. IOP Conf. Series: Earth and Environmental Science 314012054

Sari,Yuliana, Syahrul Ramadhan, dan Yulianti Rasyid. (2018). Hubungan Antara Keterampilan Membaca Pemahaman Dengan Keterampilan Menulis Teks Laporan Hasil Observasi Siswa Kelas X SMK Negeri 3 Padang. Jurnal Pendidikan Bahasa dan Sastra Indonesia. Vol. 7, No.3

Suardi, Indah Permatasari, Syahrul R, dan Yasnur Asri. (2019). Pemerolehan Bahasa Pertama pada Anak Usia Dini. Jurnal Obsesi : Jurnal Pendidikan Anak Usia Dini. Vol. 3, No. 1

Sukma, Elfia, Ahmad Johari (2016). Kompetensi kognitif pembelajaran apresiasi sastra di sekolah dasar. Jurnal Gramatika. Vol. 2 No.1

Sukma, E. (2016). Pembelajaran sastra yang 4ntegrative berbasis kompetensi. Proceeding of International Seminar on Languages and Arts: (ISLA), Atlantis Press.

Sukma, E. (2005). Penerapan Pendekatan Komunikatif dalam Pembelajaran Struktur Bahasa Indonesia di Sekolah Dasar. Jurnal Diksi. Vol. 2, No.1

Sukma, Elfia, R. Mahyudin, Rahmatina, dan A.Surian. (2019). Problems In Oral Language Teaching In Primary School. Advances in Social Science, Education and Humanities Research. Vol. 301

Syahrul, R., Elfia S, Indriyani V. (2019). Persepsi Guru Terhadap Penggunaan Bahan Ajar Bahasa Indonesia Dengan Perangkat Seluler dan Aplikasi Edmodo. Seminar Internasional Riksa Bahasa XIII. 